\title{
25 Research Square \\ The Role of Weed Seed Contamination in Grain Commodities as Propagule Pressure
}

\section{Mafumi lkeda}

Kyoto University: Kyoto Daigaku

\section{Takeshi Nishi}

Kyoto University: Kyoto Daigaku

\section{Motoaki Asai}

NARO

\section{Takashi Muranaka}

North Asia University: North Asia Daigaku

\section{Akihiro Konuma \\ NARO}

\section{Tohru Tominaga}

Kyoto University: Kyoto Daigaku

Yoshiko Shimono ( $\square$ yotti@kais.kyoto-u.ac.jp )

Kyoto University https://orcid.org/0000-0002-3432-0614

\section{Research Article}

Keywords: Establishment success, International grain trade, Residence time, Unintentional introduction

Posted Date: February 23rd, 2021

DOI: https://doi.org/10.21203/rs.3.rs-220124/v1

License: (9) This work is licensed under a Creative Commons Attribution 4.0 International License. Read Full License

Version of Record: A version of this preprint was published at Biological Invasions on February 17th, 2022. See the published version at https://doi.org/10.1007/s10530-022-02741-6. 


\section{Abstract}

The international grain trade is a major pathway for the introduction of alien plants because grain commodities can be contaminated with various weed seeds. To evaluate how alien weed seeds derived from imported grain commodities affect local vegetation in international trading ports, we conducted a vegetation survey on a set of grain landing ports and non-grain landing ports in nine regions throughout Japan to compare the vegetation between these two types of ports. We also surveyed weed seed contamination of wheat imported into Japan, and the contamination rate was calculated for each species based on our survey and previous studies on weed seed contamination. The vegetation clearly differed between the grain landing ports and the non-grain ports. In the grain landing ports, alien species were more abundant than in non-grain landing ports. All indicator species of the grain landing ports were reported to be contaminants in grain commodities. Furthermore, there was a tendency for the more abundant species at the grain landing ports to show higher contamination rates in grain commodities. These results indicate that contaminant seeds spill from imported grain in grain landing ports, and highly contaminated species are likely to become established. We clearly show that weed seed contamination in grain commodities plays an important role in propagule pressure. Gathering information about the prevalence of weeds in grain-exporting countries and monitoring the weed species composition in imported grain commodities is becoming increasingly important for predicting the unintentional introduction of troublesome weeds and identifying effective weed management options.

\section{Introduction}

An expansion of international trade has promoted the introduction and spread of alien species beyond their native range. Biological invasion has received considerable attention because invasive alien species often cause biodiversity losses, ecosystem modifications, and deleterious impacts on the economy (Mack et al. 2000; Pimentel et al. 2001).

Potential alien species must successfully go through several stages to become fully invasive (Williamson and Fitter 1996; Blackburn et al. 2011). The first stage is introduction: species are brought into new locations beyond the limits of the native range. The second is establishment: species make selfsustaining populations in locations where they are introduced. The third is spread: species expand their distribution in new locations away from the point of introduction.

Many studies have focused on the establishment and spread stages to identify species traits associated with invasiveness or habitat characteristics associated with susceptibility to invasion (Burke and Grime 1996; Pyšek and Richardson 2007; Divíšek et al. 2018; Van Boheemen et al. 2019). During the last decade however, propagule pressure (the number of individuals released into a region where they are not native and the number of introduction events per unit time) has been recognized as one of the most important factors for successful establishment and spread in alien species invasions (Holle and Simberloff 2005; Lockwood et al. 2005; Simberloff 2009). Colautti et al. (2006) proposed that propagule pressure should form the basis of a null model for invasive studies. Although some studies have evaluated the role of 
propagule pressure in the case of intentional introductions for tree plantations (Pyšek et al. 2009), ornamental plants (Lavoie et al. 2016), or pet birds (Cassey et al. 2004), few researchers have examined the empirical relationships between propagule pressure and successful establishment in the case of unintentional introduction (see Lee and Chown 2009; Lawrence and Cordell 2010).

The international grain trade is a major pathway of unintentional introduction (Hulme 2009) because various weed seeds contaminate grain commodities (Asai et al. 2007; Shimono and Konuma, 2008; Michael et al. 2010; Wilson et al. 2016). Japan is a global leader among grain-importing countries; approximately 25 million tons of grain are imported each year (Ministry of Agriculture, Forestry, and Fisheries 2020). Consequently, a large number of weed seeds are unintentionally introduced into Japan. These weed seeds spill out of grain commodities during unloading, transportation, and usage, and some of them establish successfully (Shimono et al. 2015). Moreover, some species derived from grain commodities have become problematic weeds in farmlands and natural habitats (Kurokawa et al. 2004; Lehan et al. 2013; Higuchi et al. 2017). Therefore, the assessment of the role of weed seeds in imported grain commodities as propagule pressure can provide basic information for effective weed management practices and prevention measures for the further introduction of alien species.

International trading ports are primary introduction sites for contaminant weed seeds in imported grain, providing a valuable model system to compare the stages between the introduction and establishment of alien species. In this study, we surveyed the weed seed contamination of wheat imported into Japan, and the contamination rate was calculated for each species based on our survey and previous studies on weed seed contamination (Asai et al. 2007; Wilson et al. 2016). We also conducted a vegetation survey on 10 grain landing ports, where relatively large amounts of grain commodities were imported every year, and 10 non-grain landing ports where cargos other than grain are imported. Then, we compared the vegetation between grain landing ports and non-grain landing ports to confirm whether there was a difference in vegetation between the two types of ports. Furthermore, we evaluated the relationship between the distribution pattern of each species at each type of port and the contamination rate of each species in grain commodities to confirm whether the species typical of grain landing ports were likely to be derived from seed contaminants in grain commodities. We also assessed the relationship between residence time (time since the introduction) and abundance of each alien species because not only propagule pressure but also residence time are crucial for determining whether a species is established (Richardson and Pyšek 2006; Pyšek et al. 2009). We evaluate the role of grain trade as propagule pressure, and our results will be useful for risk assessment of the alien species introduction pathways to avoid further ecological and economic losses.

\section{Methods}

Study sites

We selected 20 international trading ports in Japan, including 10 grain landing ports and 10 non-grain landing ports (Fig. 1). The grain included cereals, rice, corn, pulses, and millet. We defined the grain 
landing port as a port where an average of two hundred thousand tons or more of grain were imported annually (Ministry of Land, Infrastructure and Transport 2020). The non-grain landing ports, where less than approximately ten thousand tons of grain were imported annually, were chosen as close as possible to each grain landing port to reduce geographical bias. We classified the two ports of Mikawa and Kitakyusyu as non-grain landing ports, although more than ten thousand tons of grain are imported annually. These ports are divided into multiple geographically separated districts, and different types of cargo are handled depending on the district. We chose study sites far from grain handling districts in the two ports (supplementary material Fig. 1).

\section{Vegetation survey}

From 2016 to 2018, we surveyed the vegetation at each port twice a year: spring (from May to June) and fall (from September to October). Twenty $100 \mathrm{~m}$ transects were set along the roads in each port. For grain landing ports, we selected the roads near silos and the entrances used by fodder companies, or the main roads used to carry cargo away from the ports. For non-grain landing ports where there are no silos and fodder companies, we selected the roads near the landing places or the main roads. All flowering or fruiting herbaceous plants were recorded along each transect with a width of $1 \mathrm{~m}$ from both road edges. Moss, woody plants, and planted horticultural plants were excluded from the records. The species were identified according to Satake et al. (1981, 1982a,b), Osada (1989), Shimizu et al. (2001), Shimizu (2003), Umezawa (2007), Yashiro (2007), Uemura et al. (2010), and Flora-Kanagawa Association (2018). The nomenclature followed Yonekura and Kajita (2003). The species were classified as native to Japan or alien, and the introduction year (the earliest record in Japan) of each alien species was identified according to Shimizu et al. (2001), Muranaka (2008), Uemura et al. (2010), and Flora-Kanagawa Association (2018).

Identification of propagules in wheat imported into Japan

We investigated the propagules derived from imported wheat. Japan imports wheat from the USA, Canada, and Australia, which, when combined, account for $99 \%$ of all wheat imports to Japan (Ministry of Finance 2020). We obtained three $20 \mathrm{~kg}$ samples of five wheat classes imported between 2006 and 2007, three classes of the US wheat (Hard Red Winter wheat: HRW, Western White wheat: WW and Dark Northern Spring wheat: DNS), one class of Canadian wheat (No.1 Canada Western Red Spring wheat: $\mathrm{CW}$ ) and two classes of Australian wheat (Australian Standard White wheat: ASW, Prime Hard wheat: $\mathrm{PH})$. Seeds other than wheat were picked out from each wheat sample following the method described by Shimono and Konuma (2008). The seeds were identified on the basis of the shape, size, color, and texture of the surface (Martin and Barkley 1961; Davis 1993; Ishikawa 1994; Guo 1998), and the number of each type was counted. To verify seed identification, some of the seeds were germinated and grown in an isolated garden to maturity, and then the plants were identified (Osada 1989; Flora of North America Editorial Committee 1993+; Flora-Kanagawa Association 2018). These seeds were provided by the National Institute for Agro-Environmental Sciences to Y. Shimono at Kyoto University and were stored in an airtight container with silica gel at room temperature $\left(20-28^{\circ} \mathrm{C}\right)$. 
Calculation of the contamination rate of each species detected from imported grain

The contamination rate of each species detected from imported grains was calculated using the data from our survey and previous studies (Asai et al. 2007; Wilson et al. 2016). Asai et al. (2007) studied weed seed contamination in imported winter crops (wheat, barley, rye, oats, and canola) in Japan, mainly from the USA, Canada, and Australia, from 1993 to 1995. Although the top three imported grains in Japan are corn, soybean, and wheat, we could not obtain corn and soybean (or other crop) samples imported into Japan. Therefore, we used data from Wilson et al. (2016). They have published a list of weed seed contaminant species reported in 947 samples of 10 imported grain crops (corn, rice, soybean, cereals, pulse, canola, sunflower, flax, millet, and sorghum) in Canada from 2007 to 2015 . More than $75 \%$ of these crops, except rice, were imported from the USA. Japan also imports $70 \%$ of corn and $70 \%$ of soybean from the USA (Ministry of Finance 2020). Therefore, the list in Wilson et al. (2016) can be substituted for propagules in Japan. In Wilson et al. (2016), the data of corn, soybean, cereals, and sorghum were used because the import volumes of the other grains from the USA into Japan were small (less than 1 million tons).

Using data from our survey and Asai et al. (2007), the relative frequency of each species was calculated by dividing the number of seeds of each species by the total number of seeds detected from each sample. Wilson et al. (2016) showed the number of lots in which seeds of each weed species had been detected. Therefore, the relative frequency of each species was calculated by dividing the number of lots in which seeds for each species were detected by the total number of lots. These values were weighted by multiplying the relative quantity of each crop import for 10 years from 2007 to 2016 (Ministry of Finance 2020; supplementary material Table 1). Finally, we calculated the average value of each species for all grains, and this value was considered the contamination rate of each weed species in each study. The contamination rate was divided into 40 ranks, and the results of the three studies were averaged.

Statistical analyses

Plants identified at the species or genus level were used for analysis. To compare the number of native and alien species between the grain landing ports and the non-grain landing ports, we used a generalized linear model (GLM) assuming a negative binomial distribution using the log-link function including the port type (grain landing port or non-grain landing port) as an independent variable. Shannon's index of diversity was calculated for each port to assess species diversity among ports. A non-metric multidimensional scaling (NMDS) analysis based on Bray-Curtis distances was conducted using the number of transects that each species was recorded at each port to assess the vegetation similarities among ports. We also performed an indicator species analysis (INSPAN) to identify representative species that can characterize each port type. We selected species with an indicator value (IV) $>0.25$, and significance level $(P$-value) $<0.05$ as the indicator species (Dufrene and Legendre 1997). We checked whether these indicator species were reported to be contaminated in imported grain using the data from our survey and previous studies (Shimizu et al. 1995; Asai et al. 2007; Wilson et al. 2016). 
To assess whether highly contaminated species were more distributed at the grain landing ports, we examined the relationship between the average contamination rate and the distribution pattern for each species. Because the above-mentioned NMDS analysis separated 20 study ports into the grain landing ports and the non-grain landing ports by axis2 in both spring and fall, we used the NMDS score of axis2 of each species as an index of how the species tended to be distributed according to the port types.

To evaluate whether high propagule pressure and long residence time are associated with the establishment success of alien species in port areas, we calculated Kendall's rank correlation coefficients between the average contamination rates or the introduction year and the abundance (total number of transects that each alien species was recorded at each port type). Six species whose introduction years were not identified, 11 species introduced before 1800, and 11 crops were excluded from the analysis.

Differences in contaminated species composition among grain samples were also assessed by using the NMDS analysis based on the data of relative frequency of each species for each grain sample. First, we compared species composition among wheat classes in our survey at the species level. Second, we compared the species composition of cereals (wheat, barley, oats, and rye) among three studies at the genus level (our survey, Asai et al. (2007) and Wilson et al. (2016)).

Statistical analyses were performed using R version 4.0.0 ( $R$ Core Team 2020).

\section{Results}

Comparison of vegetation between grain and non-grain landing ports

In total, 612 species were recorded within 64 families; 601 species were identified to the species level and 11 to the genus level (supplementary material Table 2 ). The Poaceae was the dominant family (123 species), followed by Asteraceae (96 species) in both seasons (Fig. 2). In grain landing ports, Brassicaceae and Amaranthaceae were the third most dominant families in spring and fall, respectively. In the non-grain landing ports, Caryophyllaceae and Fabaceae were the third most dominant families in spring and fall, respectively. A total of 238 alien species and 141 native species were recorded in spring, and 220 alien species and 223 native species were recorded in fall. The numbers of alien species per port in spring and fall were significantly higher in the grain landing ports (mean \pm standard error: $66.4 \pm 6.22$ and $50.0 \pm 2.39$ ) than in the non-grain landing ports ( $49.5 \pm 4.60$ and $40.4 \pm 2.83)$ (spring: $P=0.024$, fall: $P$ $=0.007$ ), but the number of native species did not differ significantly between the port types in both seasons (Fig. 3). As a result, Shannon's indices of diversity for the grain landing ports $(6.05 \pm 0.14$ and $5.95 \pm 0.06)$ were slightly higher than those of non-grain landing ports $(5.79 \pm 0.13$ and $5.87 \pm 0.10)$ in both seasons.

The NMDS analysis showed that the 20 study ports were separated along the latitudinal gradient, Hokkaido, Tohoku, and the western area from Kanto by axis1 and were separated into the grain landing ports and the non-grain landing ports by axis2 in both spring and fall (Fig. 4). This indicated that vegetation was not only strongly affected by climate but also by port types. 
According to the INSPAN, 16 indicator species were identified for the grain landing ports in spring (Table 1a). Among them, three species (wheat, barley, and rapeseed) were crops. All the remaining 13 weed species were reported to be contaminants in imported grains. Only two indicator species, white clover (Trifolium repens) and slender rush (Juncus tenuis), were identified for the non-grain landing ports in spring (Table 1a). White clover was reported to be a contaminant in imported grains. In the fall, all six indicator species of the grain landing ports and one of six indicator species of non-grain landing ports were reported as contaminant species (Table $1 \mathrm{~b}$ ). The indicator species of the grain landing ports were recorded in almost all the grain landing ports, while the indicator species of the non-grain landing ports were also frequently recorded in the grain landing ports (supplementary material Fig. 2).

\section{Contaminant seed composition in wheat}

A total of 59,229 contaminant seeds were detected from the wheat samples, belonging to 92 types from 15 families (supplementary material Table 3). Seventy-three were identified at the species level, 17 to the genus level, and 2 to the family level. Poaceae was the most dominant family, with 25 types, followed by Brassicaceae (17), Polygonaceae (12), Asteraceae (8), and Amaranthaceae (6). The number of contaminant seeds per $20 \mathrm{~kg}$ of the wheat sample ranged from 375 to 6,975 .

The species composition was different among the wheat classes (Fig. 5). Two classes of winter wheat from the USA (HRW and WW) contained many seeds of cheatgrass (Bromus tectorum), wild oats (Avena fatua), and jointed goatgrass (Agilops cylindrica). One class of spring wheat from the USA (DNS) contained many seeds of Setaria species and wild oats. Seeds of oilseed rape (Brassica spp.) were the most abundant in Canadian wheat (CW). Seeds of annual ryegrass (Lolium spp.) accounted for $75 \%$ of all contaminants in one class of Australian wheat (ASW). Another class of Australian wheat (PH) was characterized by seeds of African turnip weed (Erucastrum austroafricanum), which were detected only in this wheat class.

The NMDS analysis of the contaminant seed composition in wheat showed remarkable differences between North America and Australia and between eastern and western Australia (Fig. 6a). There was a moderate difference between winter and spring wheat in North America.

The differences in the contaminant seed composition of cereals among countries also appeared even if the studies were analyzed together (Fig. 6b). The composition of the 2010 s cereals, mainly from the USA (Wilson et al. 2016), was similar to that of the 2000s DNS USA wheat. However, there were some differences in the composition of wheat imported from the USA in the 1990s (Asai et al. 2007) and the 2000 s (our survey). The 1990s wheat from the USA in Asai et al. (2007) had a higher proportion of seeds of burningbush (Bassia scoparia), barnyardgrass (Echinochloa crus-gallivar. crus-galli), Rumex spp., but no seeds of jointed goatgrass, which were abundant in the 2000s winter wheat from the USA in our survey. The weed seed compositions of Canadian grains were roughly similar between the 1990s (Asai et al. 2007) and the 2000s (our survey), although the Canadian grain in Asai et al. (2007) had a high proportion of seeds of corn spurry (Spergula arvensis); however, the seeds were not detected in CW in our survey. 
Relationship between the distribution pattern and the contamination rate

The NMDS analysis based on the vegetation at each port separated 20 ports into the grain landing ports and the non-grain landing ports by axis2 in both spring and fall (Fig. 4). Therefore, we used the NMDS score of axis2 of each species as an index of how the species tended to be distributed according to port types; species with positive scores were distributed more in the grain landing ports, and species with negative scores distributed more in the non-grain landing ports. The scatter plots between the NMDS scores of axis2 and the average contamination rates showed that species with positive scores tended to have higher contamination rates than species with negative scores in both seasons, indicating that species whose distribution was biased in the grain landing ports tended to show high contamination rates (Fig. 7). There was only one species, yellow foxtail (Setaria pumila), with a negative score and a high contamination rate of more than 10. Only sunflower (Helianthus annuus) and jointed goatgrass were not confirmed to be established despite contamination rates of more than rank 10.

Factors affecting abundance of alien species at ports

The contamination rate was positively correlated with the abundance of alien species recorded at grain landing ports, but not with the abundance of alien species recorded at non-grain landing ports in both seasons (Fig. 8a). The introduction year was negatively correlated with the abundance regardless of the port type and season (Fig. 8b). Most of the highly abundant species were first recorded before 1950 . These results indicate that weed seed contamination plays a role as a propagule pressure only at the grain landing ports, while a longer residence time promotes the establishment of alien species at both ports.

\section{Discussion}

Our study revealed that the vegetation was clearly different between the grain landing ports and the nongrain landing ports throughout Japan (Fig. 4). Alien species were more abundant in the grain landing ports than in the non-grain landing ports in spring and fall (Fig. 3). In the grain landing ports, Brassicaceae and Amaranthaceae species were recorded more frequently than in the non-grain landing ports (Fig. 2). Both were the dominant families in contaminant species in imported grains (Shimono and Konuma 2008; Wilson et al. 2016; Gervilla et al. 2019). Furthermore, all the indicator species of the grain landing ports in both seasons were reported to be contaminated in imported grain (Table. 1) and there was a tendency that more abundant species at the grain landing ports to show high contamination rates (Fig. 7, 8). These results indicate that seeds of contaminant species spilled from imported grains establish and increase species diversity in the grain landing ports. Actually, there was a positive relationship between the number of transects where wheat was recorded and the volume of imported cereals at each port (supplementary material Fig. 3).

We calculated the contamination rates based on three studies. The survey years varied from 1993 to 2015 according to the particular study. Weed species composition may have changed over the past 20 years. As the NMDS analysis showed that the contaminant seed composition of cereals was different 
between countries, even if the studies were analyzed together (Fig. 6b), it could be said that there has been no major change in 20 years. However, there were some differences in the contaminants in wheat imported from the USA in the 1990s (Asai et al. 2007) and in the 2000s (our survey). This may indicate a change in weed flora in the agricultural fields in grain-exporting countries, or it may be due to different sampling methods.

Only one species, yellow foxtail, was more widely distributed in the non-grain landing ports despite its high contamination rate. This species, native to Eurasia, is a common weed all over the world and also in Japan (Steel et al. 1983). As this cosmopolitan species is abundant throughout Japan, the effect of introduction by imported grain could be ambiguous.

Like the yellow foxtail, there are many cosmopolitan species contained in imported grains, such as lamb's quarters (Chenopodium album), shepherd's purse (Capsella bursa-pastoris), barnyardgrass, and green foxtail (Setaria viridi). Various lineages, which have different genetic compositions from the strains native to Japan, have been introduced from foreign countries because some of them, such as mouse-ear cress (Arabidopsis thaliana) (Platt et al. 2010) and shepherd's purse (Cornille et al. 2016), show geographically structured genetic variation. Therefore, non-native lineages with high reproduction capabilities may expand and displace native lineages, as has occurred in Phragmites australis (Saltonstall 2002; Pyšek et al. 2018). Given a lack of reproductive barriers between native and non-native lineages, there is a risk of hybridization between them. Heterosis achieved by hybridization enhances invasiveness (Ellstrand and Schierenbeck 2000).

Sunflower and jointed goatgrass were not established at any port despite their high contamination rates. Sunflower has been cultivated in Japan for more than 300 years and occasionally escapes, but it has rarely become established in Japan (Flora-Kanagawa Association 2018). This species may not be able to adapt to wild environments in Japan and, thus, fails to establish. The causes of a failed establishment can be estimated by comparing life-history traits between species that failed to establish and those that succeeded in establishing. This framework is invaluable for understanding the process of biological invasion because few studies have considered the effect of different life-history syndromes on the relationship between establishment success and the numbers introduced (Cassey et al. 2014). However, it is unknown whether the lineages that have been cultivated in Japan and the lineages that have been introduced by the grain trade have similar ecological traits. For example, velvetleaf (Abutilon theophrasti), introduced as a contaminant in imported grains in the 1990s, was ecologically, morphologically, and genetically different from one that had been cultivated since the 1800s in Japan (Kurokawa et al. 2004). The former has become a troublesome weed in summer row crops in Japan.

On the other hand, jointed goatgrass was first recorded in Japan in 1973. It became a troublesome weed with changes in wheat production practices since 1970s in the USA (Donald and Ogg 1991). Jointed goatgrass cannot be controlled in winter wheat by herbicides because it is genetically related to wheat, and the spikelets are similar in size to wheat seeds, which makes its removal from contaminated grain difficult (Donald and Ogg 1991). Although the seeds of jointed goatgrass were abundant in the 2000s 
winter wheat from the USA in our survey, they were not detected in the 1990s wheat from the USA (Asai et al. 2007). Thus, the introduction of this species into Japan is thought to have increased over the last few decades. Many successful colonizing species have been resident for more than 50 years (Fig. 8b). Therefore, the unsuccessful establishment of jointed goatgrass may relate to short residence time. It will be necessary to investigate carefully whether this species will establish and increase in Japan in the future.

Moreover, herbicide-resistant weeds such as palmer amaranth (Amaranth palmeri) have been increasing in recent years worldwide (Gaines et al. 2010). Highly contaminating species are known as major weeds in farmlands, and these species are often reported to be herbicide-resistant (Owen et al. 2014). Herbicideresistant weed seeds have been reported as contaminants in commercial grains (Michael et al. 2010; Shimono et al. 2010), and the establishment of herbicide-resistant weed species is common at major grain landing ports in Japan (Shimono et al. 2015; Shimono et al. 2020). Gene flow via pollen or seed movement from resistant plants could promote the rapid expansion of resistance alleles to previously herbicide-susceptible populations (Busi et al. 2011).

Thus, it is becoming increasingly important to monitor the occurrence of weeds in grain-exporting countries and the weed species composition in imported grain commodities to predict the contamination of troublesome weeds and identify effective weed management options.

\section{Conclusion}

Although it has long been recognized that various weed seeds are contained in imported grains, the relationship between the establishment and the number of individuals introduced has not previously been evaluated. We have revealed that grain commodities play an important role in propagule pressure. Our findings support previous studies showing propagule pressure is one of the best predictors for the establishment success of alien species (Lockwood et al. 2005; Simberloff 2009). Furthermore, our results show there is a relationship between propagule pressure and successful establishment, even in the case of unintentional introductions. The management of pathways represents the frontline in the prevention of biological invasions. Knowledge of the goods traded and their origin and destination should enable reasonable estimates of the risk of alien species introduction.

\section{Declarations}

\section{Acknowledgments}

We thank R. Miura, M. Mizuta, S. Uemura, and Y. Ueno for useful advice, members of Experimental Farm Management Division, NIAES for assistance with wheat sorting, and T. Kurosawa for their helping with our field work. This study was partly supported by Japanese Society for the Promotion of Science KAKENHI Grant Number 16K07230 awarded to Y. Shimono. We would like to thank Editage (www.editage.com) for English language editing. 


\section{Funding}

This study was funded by Japanese Society for the Promotion of Science KAKENHI Grant Number $16 \mathrm{~K} 07230$.

\section{Conflicts of interest/Competing interests}

There are no conflicts of interest to declare.

\section{Availability of data and material}

All data used herein are included in this manuscript and its supplementary information files.

\section{Code availability}

Non-applicable.

\section{Authors' contributions}

YS conceived the ideas; MI, TN, MA and YS collected data; MI, TN, and YS analyzed the data; TM prepared the alien plant information list: AK prepared wheat samples; MA and TT gave useful advice; MI and YS wrote the paper.

Additional declarations for articles in life science journals that report the results of studies involving humans and/or animals

Non-applicable.

\section{Ethics approval}

Non-applicable.

\section{Consent to participate}

All authors have consented to participate in this study.

\section{Consent for publication}

All authors have consented to publish of the manuscript.

\section{References}

Asai M, Kurokawa S, Shimizu N, Enomoto T (2007) Exotic weed seeds detected from imported small cereal grains into Japan during 1990s'. J Weed Sci Technol 52:1-10 
Blackburn TM, Pyšek P, Bacher S, Carlton JT, Duncan RP, Jarošík V, Wilson JRU, Richardson DM. (2011) A proposed unified framework for biological invasions. Trends Ecol Evol 26:333-339

Burke MJW, Grime JP (1996) An experimental study of plant community invasibility. Ecol 77:776-790

Busi R, Michel S, Powles SB, Délye C (2011) Gene flow increases the initial frequency of herbicide resistance alleles in unselected Lolium rigidum populations. Agri Ecosyst Environ 142:403-409

Cassey P, Blackburn TM, Sol D, Duncan RP, Lockwood JL (2004) Global patterns of introduction effort and establishment success in birds. P Roy Soc B-Biol Sci 271:405-408

Cassey P, Prowse TAA, Blackburn TM (2014) A population model for predicting the successful establishment of introduced bird species. Oecologia 175:417-428

Colautti RI, Grigorovich IA, Maclsaac HJ (2006) Propagule pressure: a null model for biological invasions. Biol Invasions 8:1023-1037

Cornille A, Salcedo A, Kryvokhyzha D, Glémin S, Holm K, Wright SI, Lascoux M (2016) Genomic signature of successful colonization of Eurasia by the allopolyploid shepherd's purse (Capsella bursa-pastoris). Mol Ecol 25:616-629

Davis LW (1993) Weed Seeds of the Great Plains: A Handbook for Identification. University Press of Kansas, Lawrence, KS

Divíšek J, Chytrý M, Beckage B, Gotelli NJ, Lososová Z, Pyšek P, Richardson DM, Molofsky J (2018) Similarity of introduced plant species to native ones facilitates naturalization, but differences enhance invasion success. Nat Commun 9:1-10

Donald WW, Ogg AG (1991) Biology and control of jointed goatgrass (Aegilops cylindrica), a review. Weed Technol 5:3-17

Dufrene M, Legendre P (1997) Species assemblages and indicator species: the need for a flexible asymmetrical approach. Ecol Monogr 67:345-366

Ellstrand NC, Schierenbeck KA (2000) Hybridization as a stimulus for the evolution of invasiveness in plants? Euphytica 148:35-46

Flora of North America Editorial Committee (1993+) Flora of North America North of Mexico. 12+ vols. New York and Oxford, USA. vol. 1, 1993; vol. 2, 1993; vol. 3, 1997; vol. 4, 2003; vol. 5, 2005; vol. 19, 2006; vol. 20, 2006; vol. 21, 2006; vol. 22, 2000; vol. 23, 2002; vol. 25, 2003; vol. 26, 2002.

Flora-Kanagawa Association (2018) Flora of Kanagawa 2018. Kanagawa Prefectural Museum of Natural History, Kanagawa 
Gaines TA, Zhang W, Wang D, Bukun B, Chisholm ST, Shaner DL, Nissen SJ, Patzoldt WL, Tranel PJ, Culpepper AS, Grey TL, Webster TM, Vencill WK, Douglas Sammons R, Jiang J, Preston C, Leach JE, Westra P. (2010) Gene amplification confers glyphosate resistance in Amaranthus palmeri. PNAS 107:1029-1034

Gervilla C, Rita J, Cursach J (2019) Contaminant seeds in imported crop seed lots: a non-negligible human-mediated pathway for introduction of plant species to islands. Weed Res 59:245-253

Guo QX (1998) Identification of Weed Seeds with Colored Pictures. China Agricultural Press, Beijing Higuchi Y, Shimono Y, Tominaga T (2017) The expansion route of ryegrasses (Lolium Spp.) into sandy coasts in Japan. Invasive Plant Sci Manag 10:61-71

Holle BV, Simberloff D (2005) Ecological resistance to biological invasion overwhelmed by propagule pressure. Ecol 86:3212-3218

Hulme PE (2009) Trade, transport and trouble: managing invasive species pathways in an era of globalization. J Appl Ecol 46:10-18

Ishikawa S (1994) Seeds / Fruits of Japan. Ishikawa Shigeo Zukan Kanko linkai, Tokyo

Kurokawa S, Shibaike H, Akiyama H, Yoshimura Y (2004) Molecular and morphological differentiation between the crop and weedy types in Velvetleaf (Abutilon theophrasti Medik.) using a chloroplast DNA marker: seed source of the present invasive Velvetleaf in Japan. Heredity 93:603-609

Lavoie C, Joly S, Bergeron A, Guay G, Groeneveld E (2016) Explaining naturalization and invasiveness: new insights from historical ornamental plant catalogs. Ecol Evol 6:7188-7198

Lawrence DJ, Cordell JR (2010) Relative contributions of domestic and foreign sourced ballast water to propagule pressure in Puget Sound, Washington, USA. Biol Conserv 143:700-709

Lee JE, Chown SL (2009) Breaching the dispersal barrier to invasion: quantification and management. Ecol Appl 19:1944-1959

Lehan NE, Murphy JR, Thorburn LP, Bradley BA (2013) Accidental introductions are an important source of invasive plants in the continental United States. Ame J Bot 100:1287-1293

Lockwood JL, Cassey P, Blackburn T (2005) The role of propagule pressure in explaining species invasions. Trends Ecol Evol 20:223-228

Mack RN, Simberloff D, Lonsdale WM, Evans H, Clout M, Bazzaz FA. 2000. Biotic invasions: causes, epidemiology, global consequences, and control. Ecol Appl 10:689-710

Martin AC, Barkley WD (1961) Seed Identification Manual. Blackburn Press, NJ 
Michael PJ, Owen MJ, Powles SB (2010) Herbicide-resistant weed seeds contaminate grain sown in the Western Australian grainbelt. Weed Sci 58:466-472

Ministry of Agriculture, Forestry, and Fisheries (2020) Supply and demand of food in Japan. https://www.maff.go.jp/j/zyukyu/fbs/. Accessed 18 Jan 2021

Ministry of Finance (2020) Trade statistics of Japan. http://www.customs.go.jp/toukei/info/tsdl.htm. Accessed 18 Jan 2021

Ministry of Land, Infrastructure and Transport (2020) Traffic-related statistics of Japan. https://www.mlit.go.jp/k-toukei/saishintoukeihyou.html. Accessed 18 Jan 2021

Muranaka T (2008) Naturalization and invasion of alien plants in Japan: relationships among their origin of use and time of introduction. Japanese $\mathrm{J}$ Conserv Ecol 13:89-101

Osada T (1989) Pcture book of Poaceae in Japan. Heibonsha, Tokyo

Owen MJ, Martinez NJ, Powles SB (2014) Multiple herbicide-resistant Lolium rigidum (annual ryegrass) now dominates across the Western Australian grain belt. Weed Res 54:314-324

Pimentel D, McNair S, Janecka J, Wightman J, Simmonds C, O'Connell C, Wong E, Russel L, Zern J, Aquino T, Tsomondo T. (2001) Economic and environmental threats of alien plant, animal, and microbe invasions. Agric Ecosyst Environ 84:1-20

Platt A, Horton M, Huahg YS, Li Y, Anastasio AE, Mulyati NW, Ågren J, Bossdorf O, Byers D, Donohue K, Dunning M, Holub EB, Hudson A, Corre VL, Loudet O, Roux F, Warthmann N, Weigel D, Rivero L, Scholl R, Nordborg M, Bergelson J, Borevitz JO (2010) The scale of population structure in Arabidopsis thaliana. PLoS Genet 6:e1000843

Pyšek P, Křivánek M, Jarošik V (2009) Planting intensity, residence time, and species traits determine invasion success of alien woody species. Ecol 90:2734-44

Pyšek P, Richardson DM (2007) Traits associated with invasiveness in alien plants: where do we stand? In: Nentwig W (ed) Biological invasions, Ecological Studies 193. Springer-Verlag, Berlin, pp97-125

Pyšek P, Skálová H, Čuda J, Guo WY, Suda J, Doležal J, Kauzál O, Lambertini C, Lučanová M, Mandáková T, Moravcová L, Pyšková K, Brix H, Meyerson LA (2018) Small genome separates native and invasive populations in an ecologically important cosmopolitan grass. Ecol 99:79-90

R Core Team (2020) R: A language and environment for statistical computing. R Foundation for Statistical Computing, Vienna, Austria. https://www.R-project.org/. Accessed 18 Jan 2021

Richardson DM, Pyšek P (2006) Plant invasions: merging the concepts of species invasiveness and community invasibility. Prog Phys Geogr 30:409-431 
Saltonstall K (2002) Cryptic invasion by a non-native genotype of the Common reed, Phragmites australis, into North America. PNAS 99:2445-2449

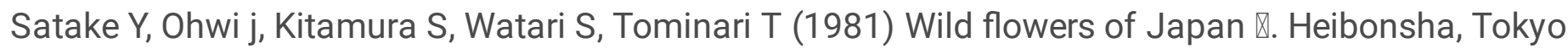
Satake Y, Ohwi j, Kitamura S, Watari S, Tominari T (1982a) Wild flowers of Japan \. Heibonsha, Tokyo Satake Y, Ohwi j, Kitamura S, Watari S, Tominari T (1982b) Wild flowers of Japan 囚. Heibonsha, Tokyo Simberloff D (2009) The role of propagule pressure in biological invasions. Annu Rev Ecol Evol Syst 40:81-102.

Shimizu N, Kurokawa S, Uozumi S (1995) Establishment and diffusion mechanisms of alien weeds invading grasslands and forage crop fields (II). J Weed Sci Technol 40:178-179

Shimizu N, Morita H, Hirota S (2001) Flora of Alien Species in Japan. Plant Invader 600 species. Zenkoku Noson Kyoiku Kyokai, Tokyo

Shimizu T (2003) Naturalized plants of Japan. Heibonsha, Tokyo

Shimono A, Kanbe H, Nakamura S, Ueno S, Yamashita J, Asai M (2020) Initial invasion of glyphosateresistant Amaranthus palmeri around grain-import ports in Japan. Plants People Planet 2:640-648

Shimono Y, Konuma A (2008) Effects of human-mediated processes on weed species composition in internationally traded grain commodities. Weed Res 48:10-18

Shimono Y, Shimono A, Oguma H, Konuma A, Tominaga T (2015) Establishment of Lolium species resistant to acetolactate synthase-inhibiting herbicide in and around grain-importation ports in Japan. Weed Res 55:101-111

Shimono Y, Takiguchi Y, Konuma A (2010) Contamination of internationally traded wheat by herbicideresistant Lolium rigidum. Weed Biol Manag 10:219-228

Steel MG, Cavers PB, Lee SM (1983) The biology of Canadian weeds. 59. Setaria glauca (L.) Beauv. and S. verticillata (L.) Beauv. Can J Plant Sci 63:711-725

Uemura S, Shimizu N, Mizuta M, Hirota S, Morita H, Katsuyama T, Ikehara N (2010) Flora of Alien Species in Japan. Volume 2. Plant Invader 500 species. Zenkoku Noson Kyoiku Kyokai, Tokyo

Umezawa S (2007) Flora of Hokkaido. Hokkaido University Press, Hokkaido

Van Boheemen LA, Atwater DZ, Hodgins KA (2019) Rapid and repeated local adaptation to climate in an invasive plant. New Phytol 222:614-627

Williamson M, Fitter A (1996) The varying success of invaders. Ecol 77:1661-1666 
Wilson CE, Castro KL, Thurston GB, Sissons A (2016) Pathway risk analysis of weed seeds in imported grain: a Canadian perspective. NeoBiota 30:49-74

Yashiro K (2007) Picture Book of Cyperaceae. Zenkoku Nouson Kyoiku Kyokai, Tokyo

Yonekura K, Kazita T (2003) BG Plants, Japanese Name-Scientific Name Index (YList). http://ylist.info. Accessed 18 Jan 2021

\section{Tables}

Table 1 Indicator species for the grain landing ports and the non-grain landing ports in spring (a) and fall (b) according to an indicator species analysis (INSPAN). Indicator species are classified into three categories; C: crop species, A: alien species and N: native species. Species with records of contamination in imported grain are checked in the last column. 
(a)

\begin{tabular}{|c|c|c|c|c|c|c|}
\hline Port type & Family & Scientific name & $\begin{array}{r}\text { Indicator } \\
\text { value }\end{array}$ & $P$-value & Category & Contamination \\
\hline \multirow{16}{*}{$\begin{array}{l}\text { Grain } \\
\text { landing port }\end{array}$} & Poaceae & Triticum aestivum & 0.900 & 0.001 & $\mathrm{C}$ & \\
\hline & Brassicaceae & Brassica napus & 0.854 & 0.002 & $\mathrm{C}$ & \\
\hline & Brassicaceae & Sisymbrium orientale & 0.773 & 0.001 & $\mathrm{~A}$ & $\square$ \\
\hline & Caryophyllaceae & Stellaria media & 0.773 & 0.002 & $\mathrm{~N}$ & $\square$ \\
\hline & Brassicaceae & Capsella bursa-pastoris & 0.767 & 0.006 & $\mathrm{~N}$ & $\square$ \\
\hline & Rubiaceae & Galium aparine & 0.756 & 0.003 & $\mathrm{~A}$ & $\square$ \\
\hline & Poaceae & Hordeum vulgare & 0.700 & 0.003 & $\mathrm{C}$ & \\
\hline & Rubiaceae & Galizon spurium var. echinosperm on & 0.700 & 0.017 & $\mathrm{~N}$ & $\square$ \\
\hline & Poaceae & Bromus dianabus & 0.687 & 0.008 & A & $\square$ \\
\hline & Malvaceae & Malva parviflora & 0.600 & 0.014 & $\mathrm{~A}$ & $\square$ \\
\hline & Poaceae & Poa anmua & 0.571 & 0.002 & $\mathrm{~N}$ & $\square$ \\
\hline & Polygonaceae & Polygonum aviculare & 0.562 & 0.048 & $\mathrm{~N}$ & $\square$ \\
\hline & Poaceae & Avena fatua & 0.547 & 0.027 & $\mathrm{~A}$ & $\square$ \\
\hline & Brassicaceae & Brassica tornefortii & 0.500 & 0.035 & $\mathrm{~A}$ & $\square$ \\
\hline & Brassicaceae & Raphanus raphanistrum & 0.500 & 0.042 & $\mathrm{~A}$ & $\square$ \\
\hline & Amaranthaceae & Amaranthus viridis & 0.470 & 0.043 & $\mathrm{~A}$ & $\square$ \\
\hline \multirow{2}{*}{$\begin{array}{l}\text { Non-grain } \\
\text { landing port }\end{array}$} & Fabaceae & Trifolium repens & 0.726 & 0.011 & $\mathrm{~A}$ & $\square$ \\
\hline & Juncaceae & Juncus tenuis & 0.588 & 0.047 & $\mathrm{~N}$ & \\
\hline
\end{tabular}

(b)

\begin{tabular}{|c|c|c|c|c|c|c|}
\hline Port type & Family & Scientific name & $\begin{array}{r}\text { Indicator } \\
\text { value }\end{array}$ & $P$-value & Category & Contamination \\
\hline \multirow{6}{*}{$\begin{array}{l}\text { Grain } \\
\text { landing port }\end{array}$} & Convolvulaceae & Ipom oea hederacea & 0.767 & 0.008 & $\mathrm{~A}$ & $\square$ \\
\hline & Amaranthaceae & Amaranthus hybridus & 0.756 & 0.004 & $\mathrm{~A}$ & $\square$ \\
\hline & Portulacaceae & Portulaca oler acea & 0.704 & 0.024 & $\mathrm{~N}$ & $\square$ \\
\hline & Amaranthaceae & Amaranthus viridis & 0.667 & 0.013 & A & $\square$ \\
\hline & Phytolaccaceae & Phytolacca americana & 0.659 & 0.006 & A & $\square$ \\
\hline & Malvaceae & Sida spinosa & 0.600 & 0.010 & $\mathrm{~A}$ & $\square$ \\
\hline \multirow{6}{*}{$\begin{array}{l}\text { Non-gr ain } \\
\text { landing port }\end{array}$} & Poaceae & Phragmites australis & 0.748 & 0.015 & $\mathrm{~N}$ & \\
\hline & Poaceae & Digitaria violascens & 0.746 & 0.019 & $\mathrm{~N}$ & \\
\hline & Poaceae & Miscanthus sinensis & 0.731 & 0.016 & $\mathrm{~N}$ & \\
\hline & Asteraceae & Symphyotrichuon subulatum & 0.630 & 0.047 & $\mathrm{~A}$ & \\
\hline & Fabaceae & Lespedeza cuneata & 0.614 & 0.026 & $\mathrm{~N}$ & \\
\hline & Asteraceae & Erigeron canadensis & 0.601 & 0.003 & $\mathrm{~A}$ & $\square$ \\
\hline
\end{tabular}

\section{Figures}




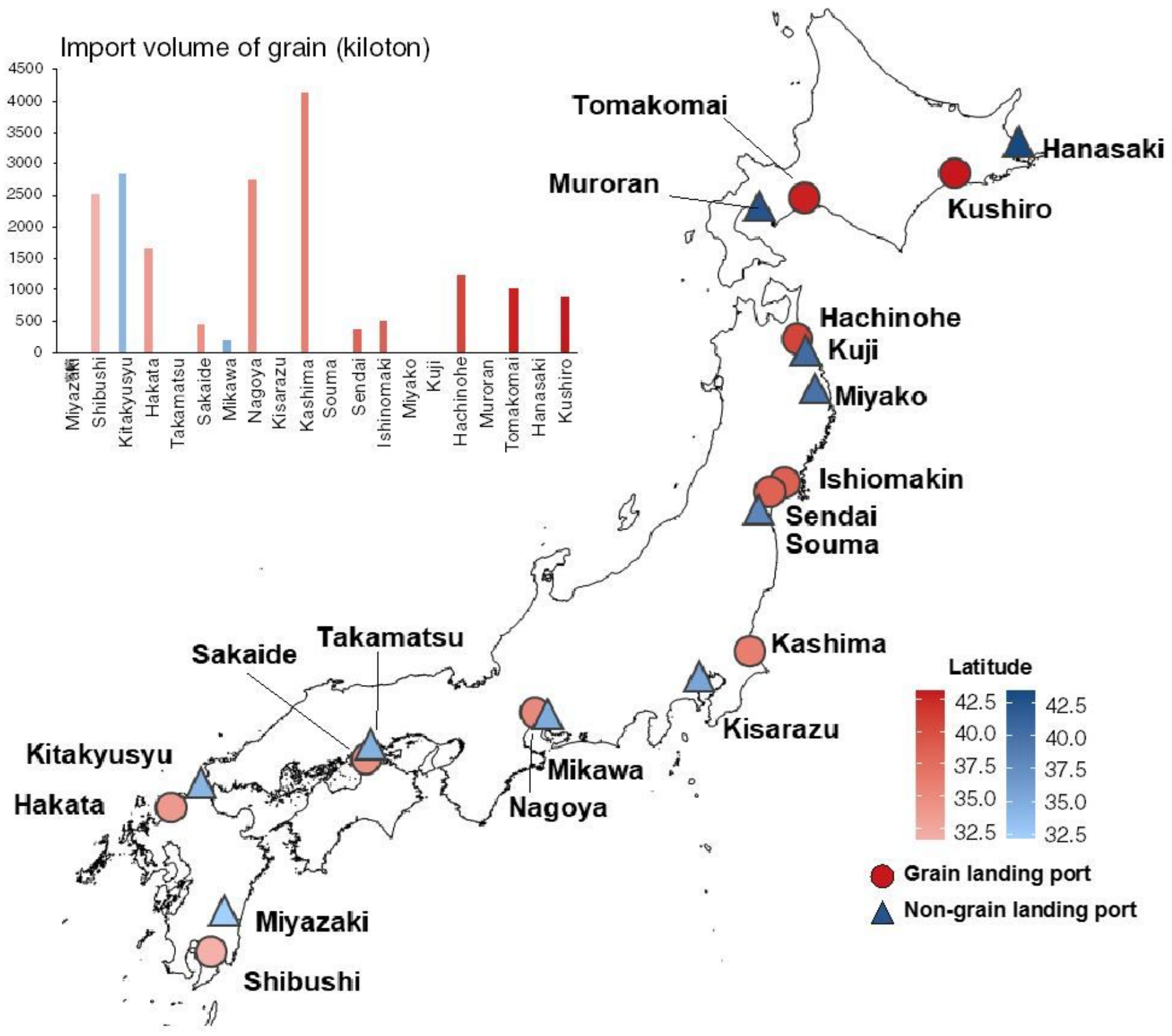

Figure 1

Locations of 20 study ports and the import volumes of grain. The volume of grain is the sum of those imported directly from overseas and those transferred from other ports in Japan. The volume is the average from 2007 to 2016. Grain includes cereals, rice, corn, pulses, and millet. Note: The designations employed and the presentation of the material on this map do not imply the expression of any opinion whatsoever on the part of Research Square concerning the legal status of any country, territory, city or area or of its authorities, or concerning the delimitation of its frontiers or boundaries. This map has been provided by the authors. 


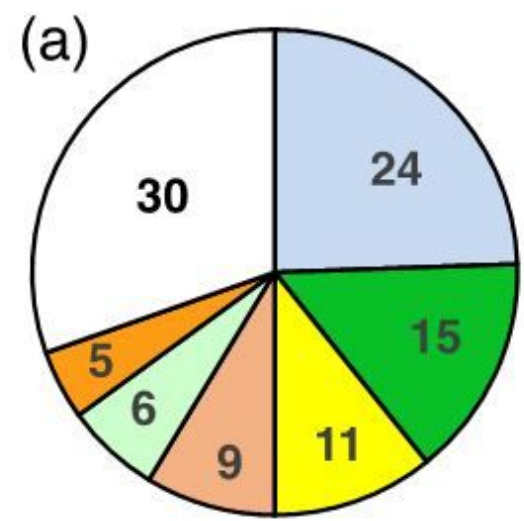

Grain landing port

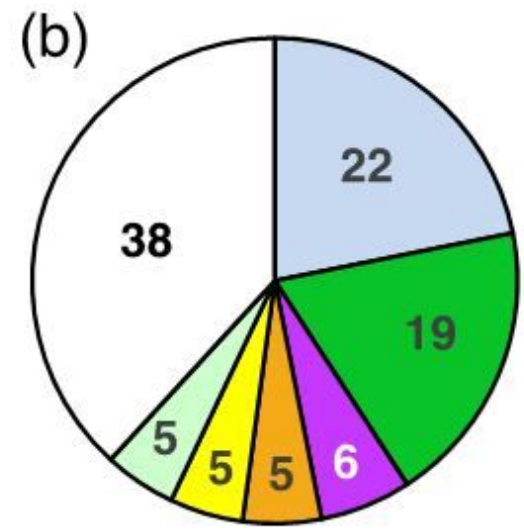

Grain landing port

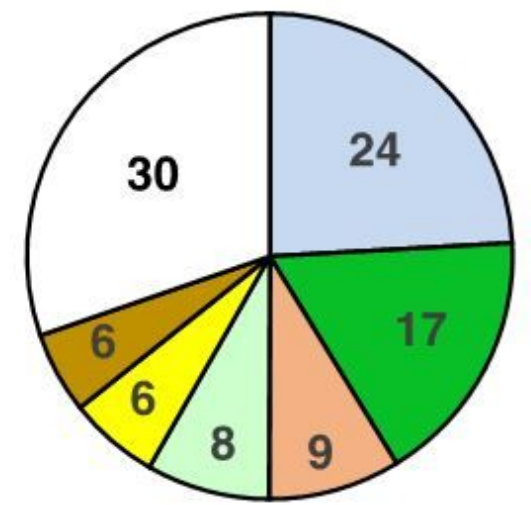

Non-grain landing port

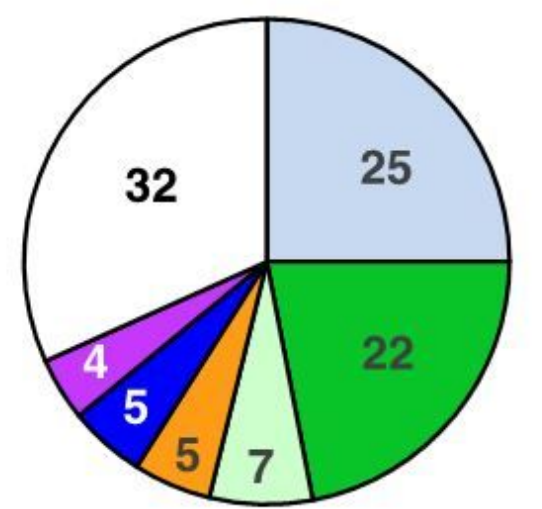

Non-grain landing port

Figure 2

Composition of the plant species at the family level in grain landing ports and the non-grain landing ports in spring (a) and fall (b). Values show percentages. 
(a)

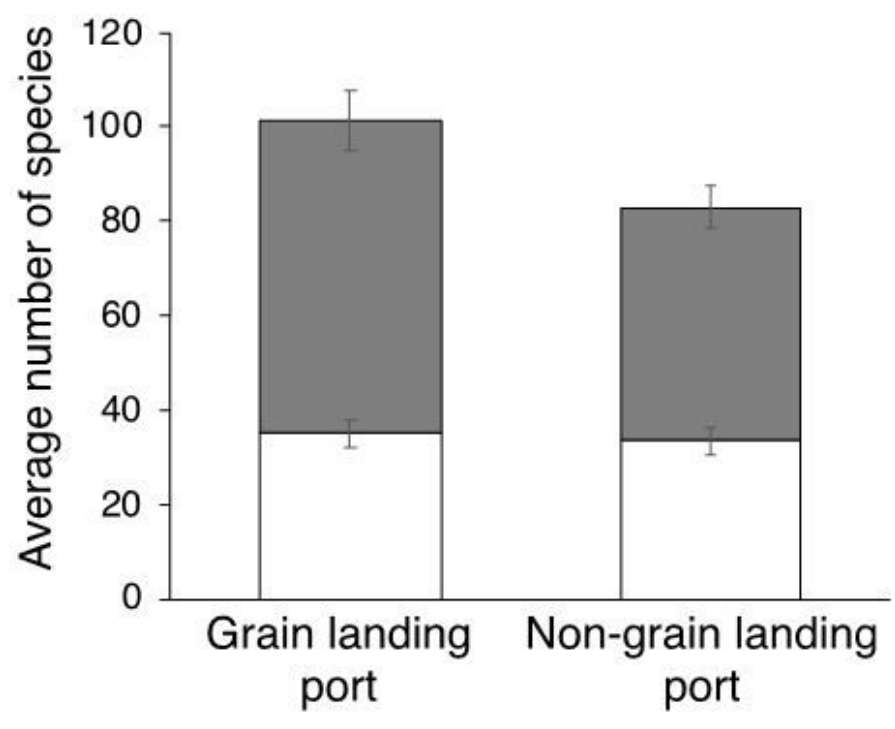

(b)

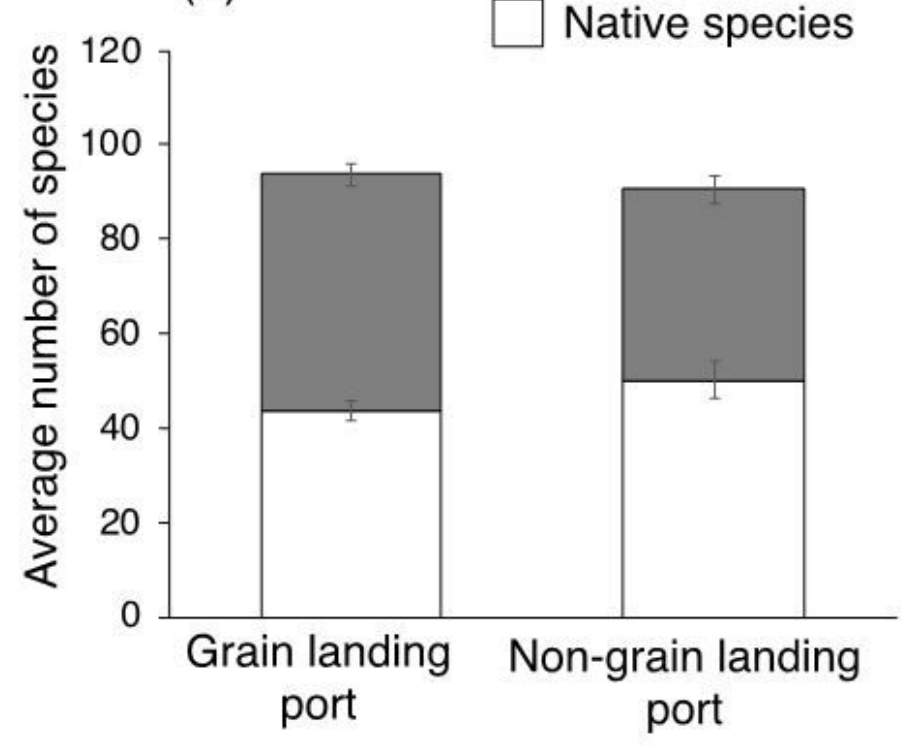

\section{Figure 3}

Average number of alien and native species in the grain landing ports and the non-grain landing ports in spring (a) and fall (b). Bars represent standard errors. 
(a)

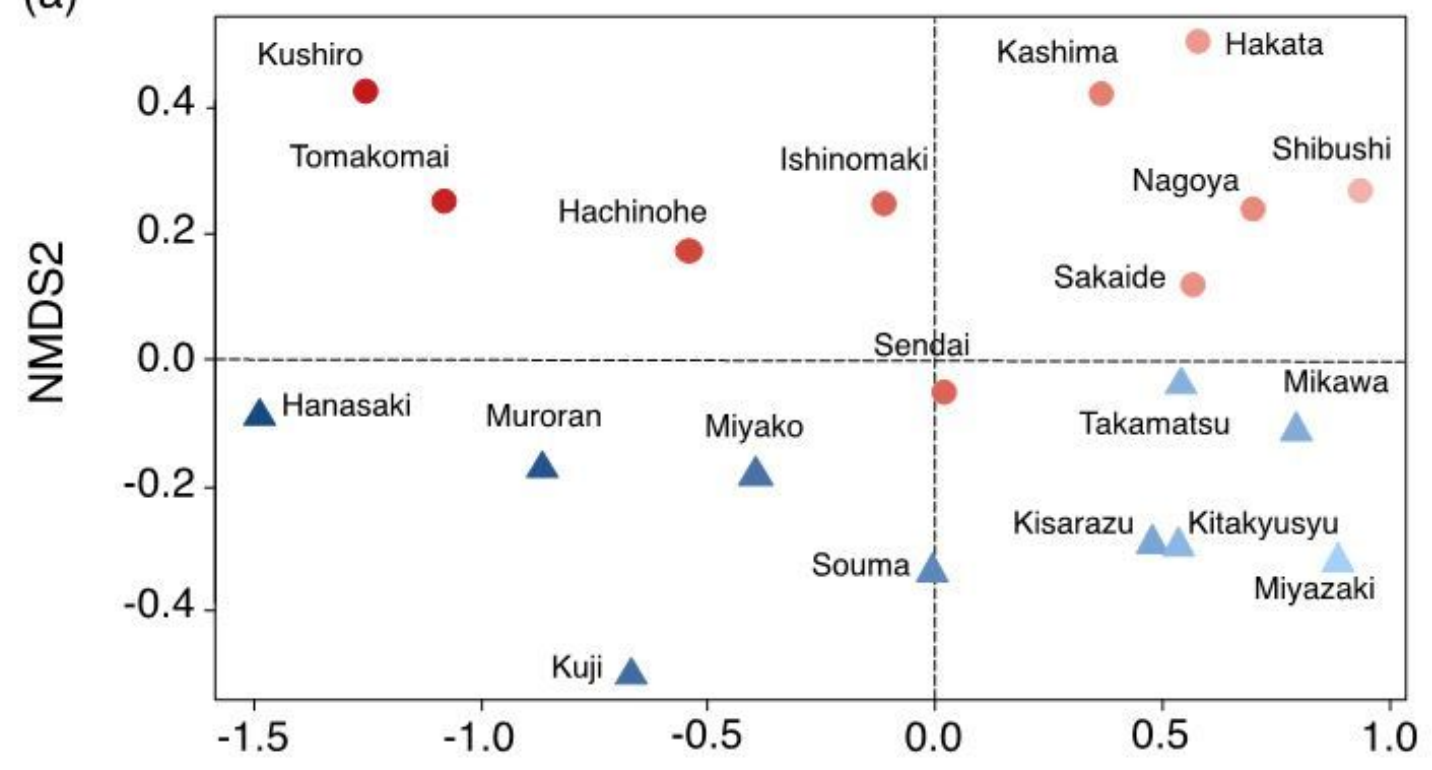

NMDS1 $($ stress value $=0.074)$

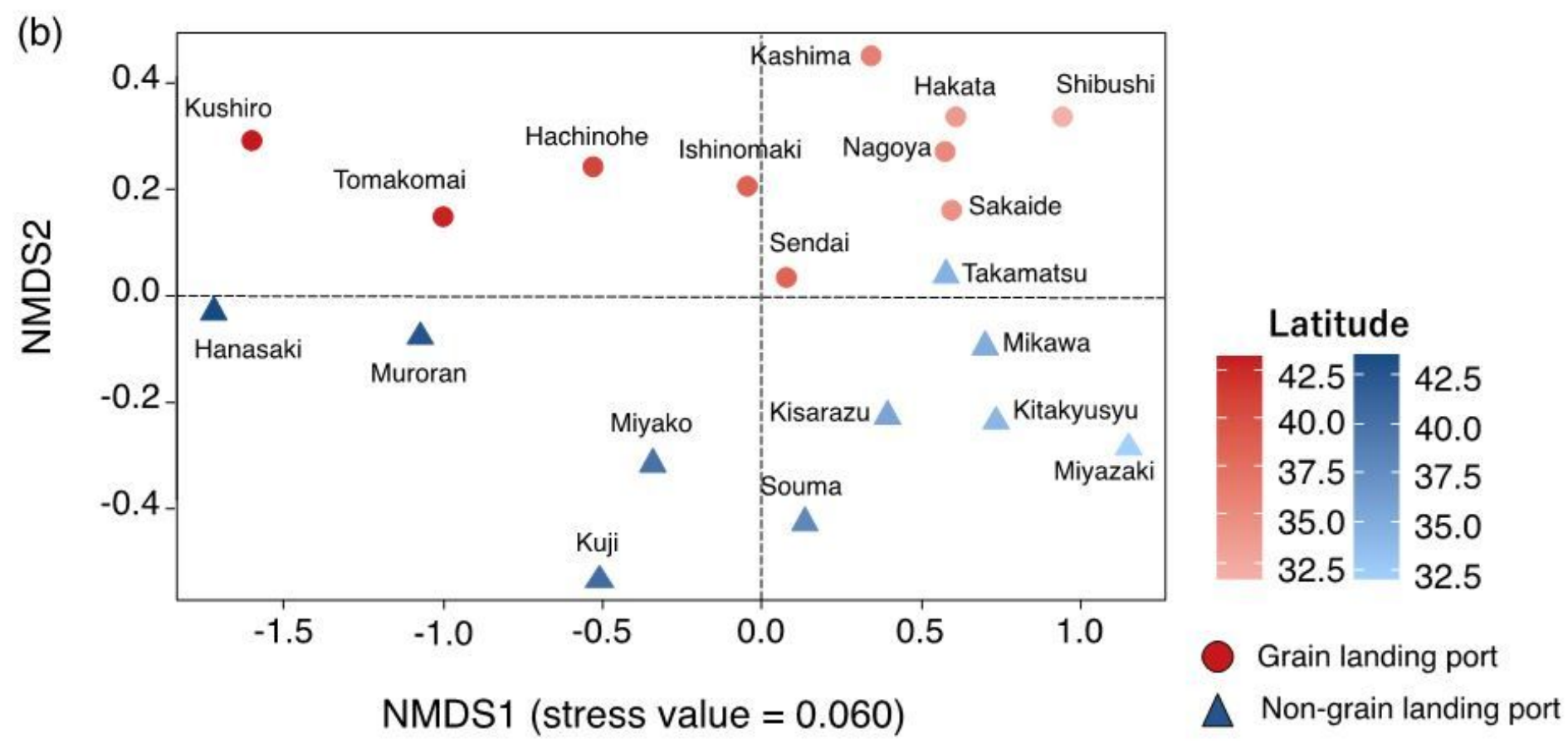

Figure 4

Non-metric multidimensional scaling (NMDS) ordination diagrams based on the plant species compositions of ports in spring (a) and fall (b). 
HRW

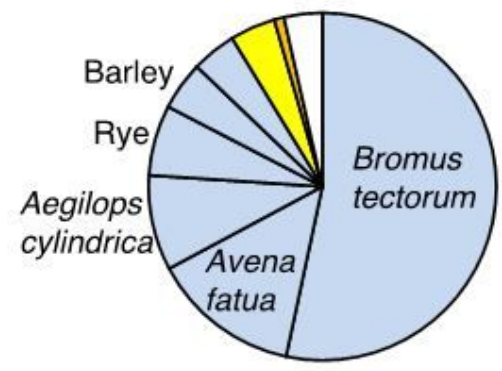

WW

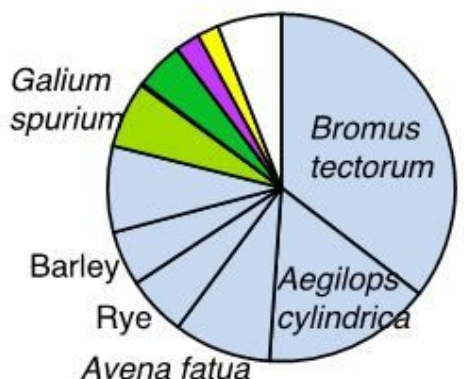

Avena fatua

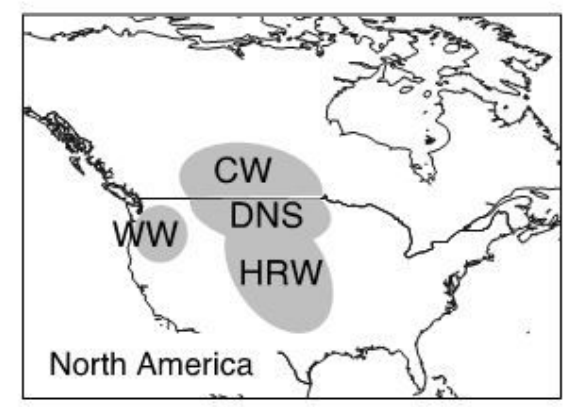

DNS

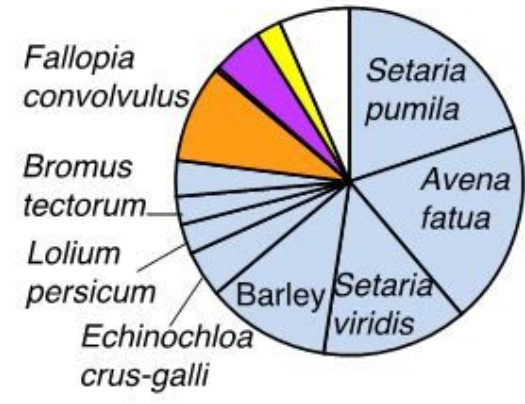

CW

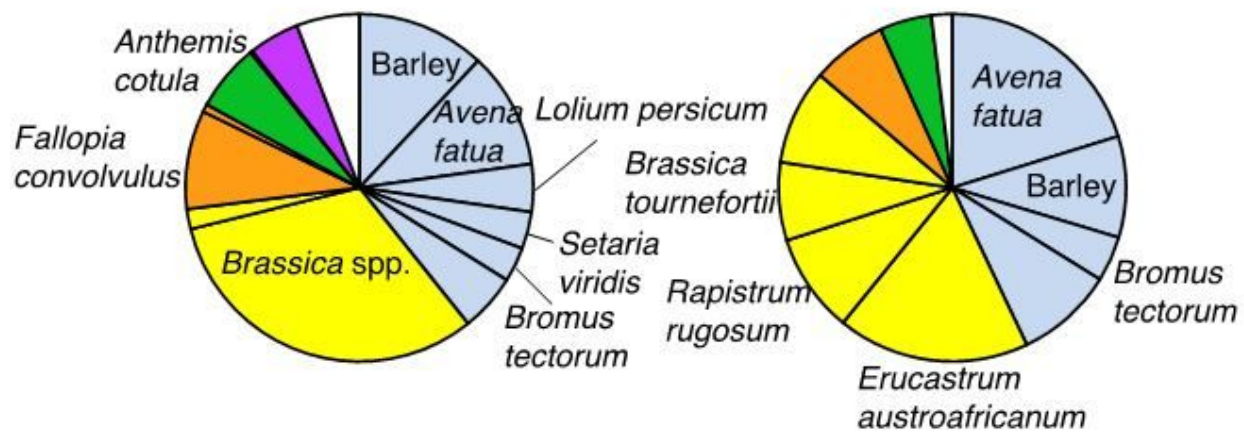

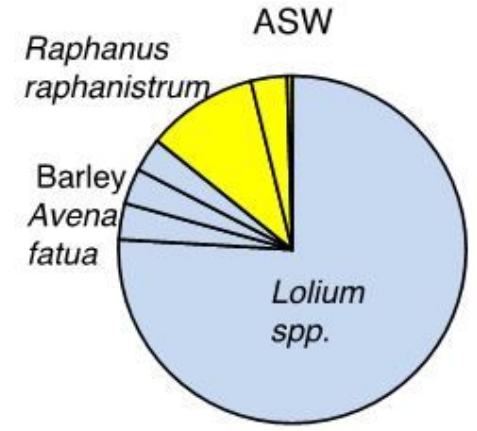

$\mathrm{PH}$ austroafricanum

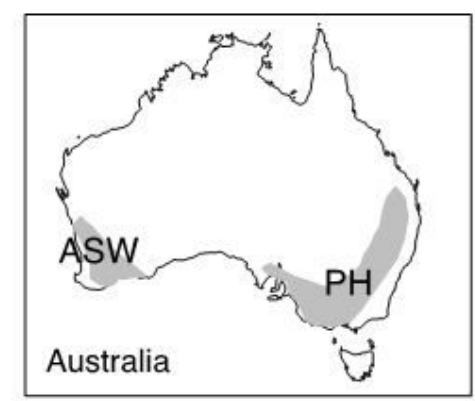

Poaceae

Brassicaceae

Polygonaceae

Asteraceae

Amaranthaceae

Rubiaceae

Others

\section{Figure 5}

Percentage distribution of the number of weed seeds detected from each class of wheat. The seeds are grouped by family. Names of species or genera with especially large numbers of seeds are shown. Bottom maps show major growing areas of each wheat class. Abbreviations are as follows: HRW, Hard Red Winter wheat; WW, Western White wheat; DNS, Dark Northern Spring wheat; CW, No.1 Canada Western Red Spring wheat; ASW, Australian Standard White wheat; PH, Prime Hard. Note: The designations employed and the presentation of the material on this map do not imply the expression of any opinion whatsoever on the part of Research Square concerning the legal status of any country, territory, city or area or of its authorities, or concerning the delimitation of its frontiers or boundaries. This map has been provided by the authors. 
(a)

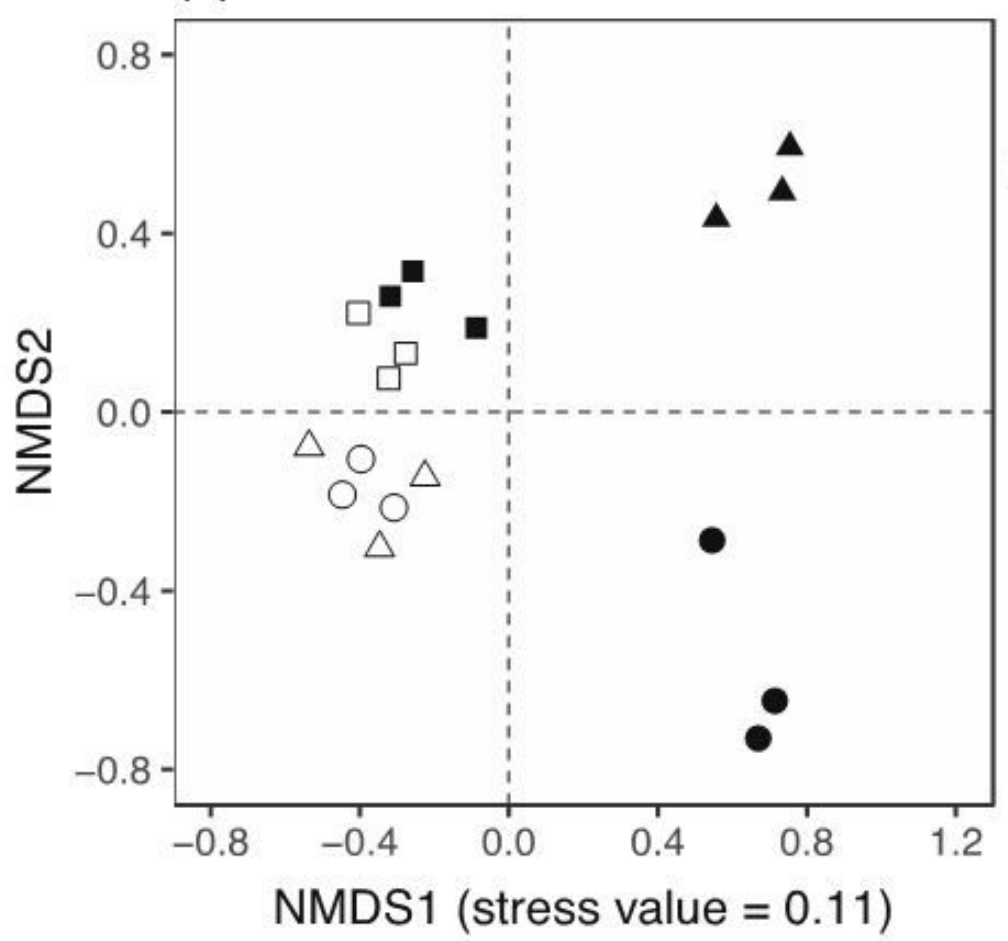

Wheat class

O HRW

$\triangle$ WW

$\square \quad$ DNS

- $\mathrm{CW}$

A ASW

- $\mathrm{PH}$

(b)

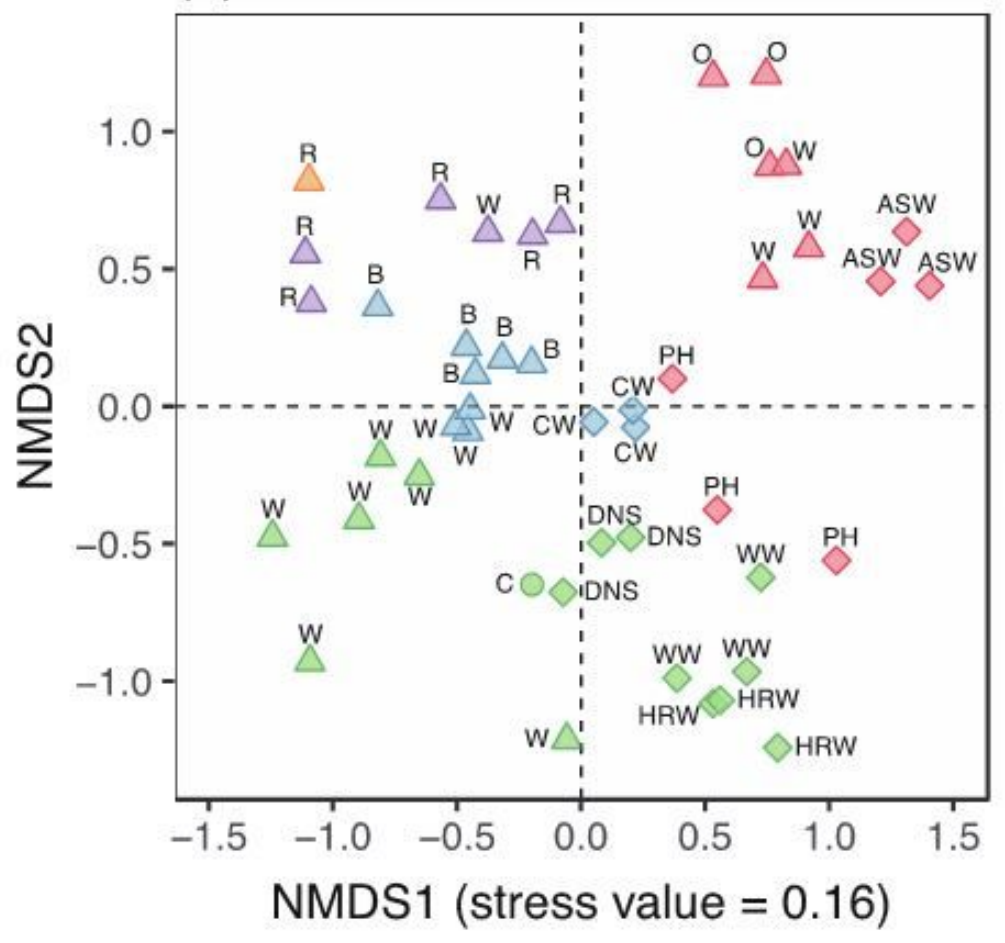

Country

- USA

- Canada

- Australia

- Germany

Finland

Study

○ Wilson et al.

$\triangle$ Asai et al.

$\diamond$ This study

\section{Figure 6}

Non-metric multidimensional scaling (NMDS) ordination diagrams based on the weed seed compositions of wheat classes (a) and cereals (wheat, barley, oats, and rye) in three studies (b). The country means the 'cereal-exporting country'. The details of the study refer to the text. Abbreviations are as follows: B, barley; C, cereals; O, oat; R, rye; W, wheat; HRW, Hard Red Winter wheat; WW, Western White wheat; DNS, Dark 
Northern Spring wheat; CW, No.1 Canada Western Red Spring wheat; ASW, Australian Standard White wheat; PH, Prime Hard wheat.

(a)

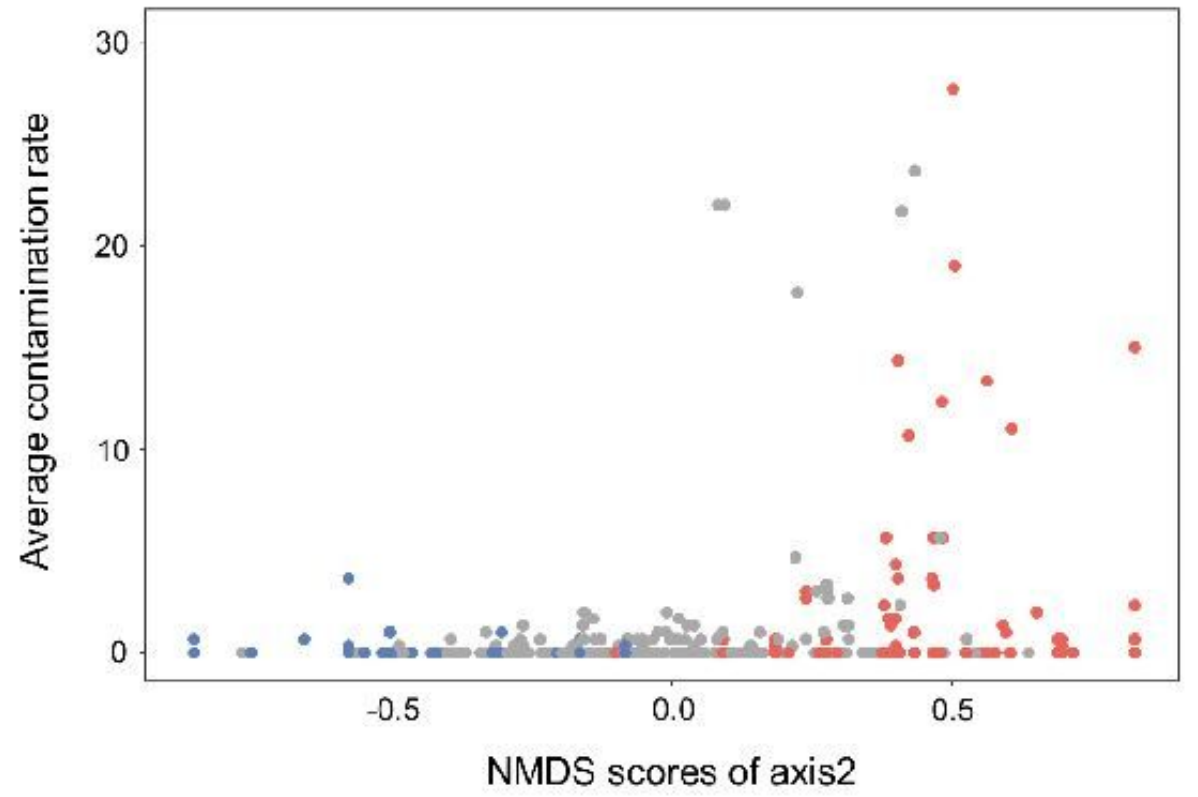

(b)

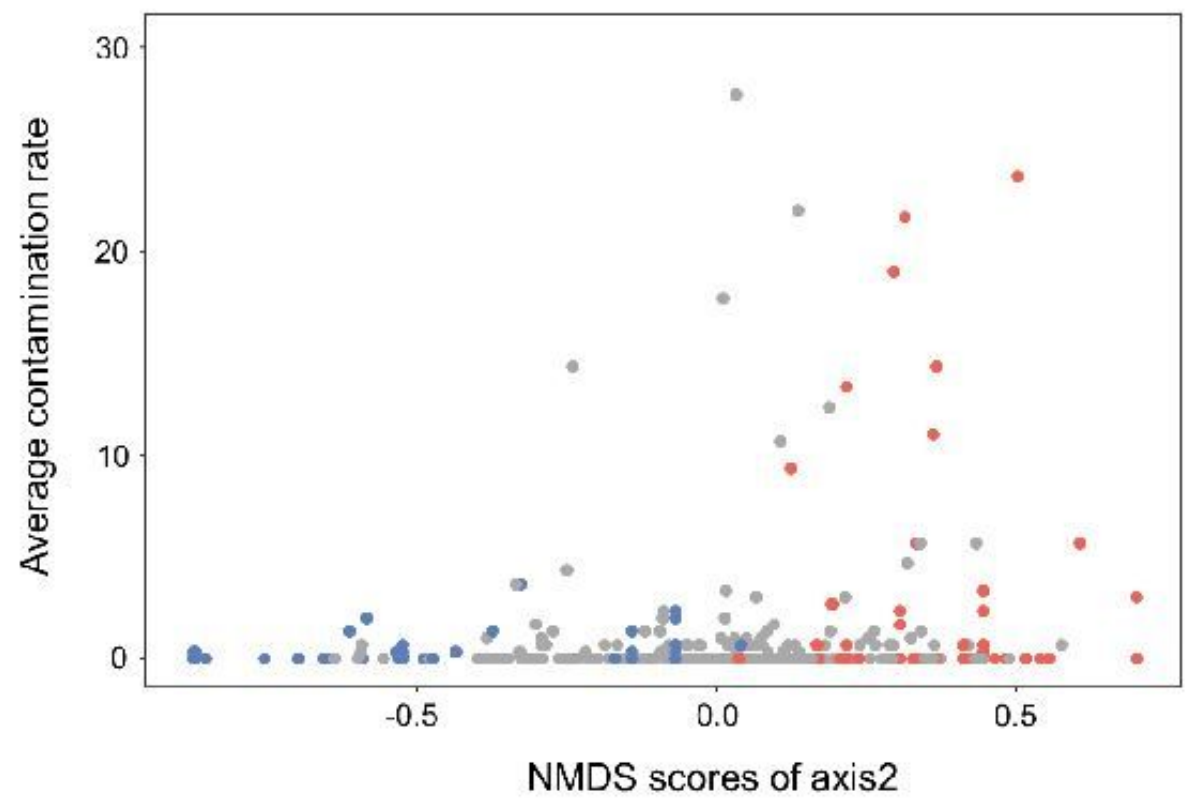

\section{Figure 7}

Relationship between the distribution pattern and the average contamination rate of each species in spring (a) and fall (b). The $x$-axis shows the NMDS score of axis2 of each species. Species with positive 
scores distributed more in the grain landing ports, and species with negative scores distributed more in the non-grain landing ports.
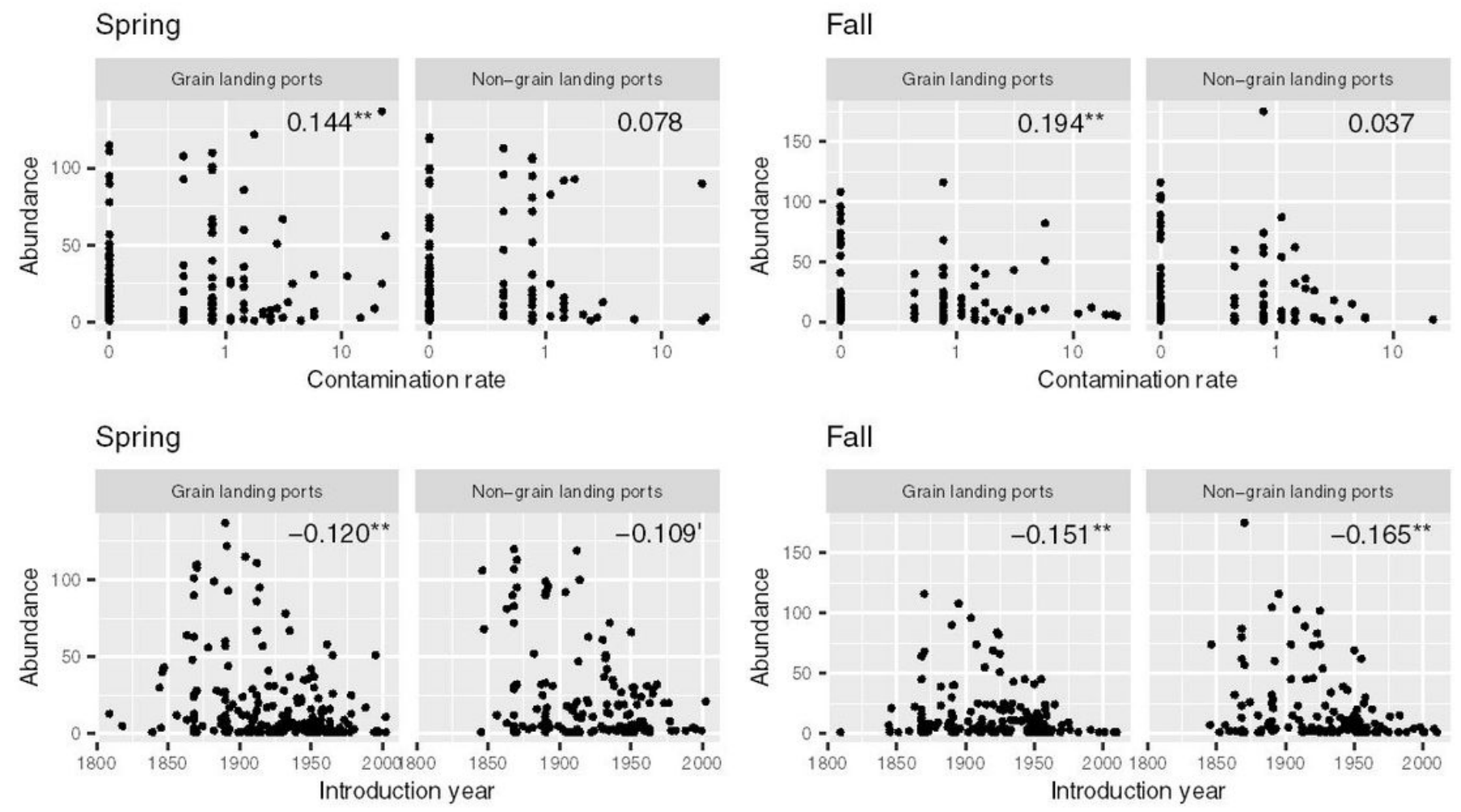

\section{Figure 8}

Relationship between contamination rate (a), introduction year (b), and abundance of alien species recorded at grain landing ports and non-grain landing ports in spring and fall (b). Kendall's rank correlation coefficients are shown. ' $P<0.06$; ${ }^{*} P<0.05 ; * \star ~ P<0.01$.

\section{Supplementary Files}

This is a list of supplementary files associated with this preprint. Click to download.

- SIFig.docx

- SITable1.pdf

- SITable2.pdf

- SITable3.pdf 